\title{
Online Child Sexual Exploitation in the Philippines: Moving beyond the current discourse and approach
}

\author{
Melinda Gill
}

Please cite this article as: M Gill, 'Online Child Sexual Exploitation in the Philippines: Moving beyond the current discourse and approach', Anti-Trafficking Review, issue 16, 2021, pp. 150-155, https://doi.org/10.14197/atr.2012211610

\section{Online Child Sexual Exploitation in the Philippines}

Online child sexual exploitation (OCSE) is a growing, global issue. OCSE refers to situations where a child 'takes part in a sexual activity in exchange for something (... or ... the promise of such), from a third party, the perpetrator, or by the child him/herself' and where the sexually exploitative images and materials at some stage involve the online environment, whether being 'produced, bought, sold, possessed, distributed, or transmitted. ${ }^{1}$ OCSE is highly interconnected with other forms of child sexual exploitation, including sexual exploitation that occurs whilst the victim is online or the grooming of children online for either online or offline sexual exploitation. ${ }^{2}$

The Philippines is often referred to as a 'hot spot' for OCSE. Since the first convictions involving OCSE in 2011, ${ }^{3}$ the number of reported cases has been rising each year, with more than 800,000 tips of possible OCSE from the Philippines in 2019. ${ }^{4}$ During the COVID-19 pandemic, tips are reported to have

1 S Greijer and J Doek, Terminology Guidelines for the Protection of Children from Sexual Exploitation and Sexual Abuse, ECPAT International with ECPAT Luxembourg, Bangkok, 2013, pp. 24-28, https://www.ecpat.org/wp-content/uploads/2016/12/ Terminology-guidelines_ENG.pdf.

$2 \quad$ Ibid.

3 Terre Des Hommes Netherlands, Fullscreen on View: An exploratory study on the background and psychosocial consequences of webcam child sex tourism in the Philippines, TDH, 2013, p. 5, https://cdn.icmec.org/wp-content/uploads/2020/07/Exploratory-Study-WebcamCSE-in-Philippines-Terre-des-Hommes-2013.pdf.

4 National Center for Missing and Exploited Children (NCMEC), CyperTipline, 2019, retrieved 24 November 2020, https://www.missingkids.org/gethelpnow/cybertipline.

This is an open-access article distributed under the terms of the Creative Commons Attribution License (CC-BY). Under the CC-BY license, the public is free to share, adapt, and make commercial use of the work. Users must always give proper attribution to the authors and the Anti-Trafficking Review. 
increased by 264 per cent. ${ }^{5}$ Widespread access to low-cost internet and mobile devices together with high levels of English proficiency and an established commercial sex industry are the most immediate explanations for the prevalence of OCSE in the country. ${ }^{6}$

Whilst the relevant stakeholders concur that more action is needed to tackle the issue, there is disagreement regarding how the problem is represented and addressed. High profile awareness and online safety campaigns portray OCSE as being perpetrated against young children by adults, usually within the same household. ${ }^{7}$ However, existing research and the experience of many communitybased practitioners suggest that self-generated sexual content/material by children is more common and becoming normalised in many communities with friends and young relatives 'coaching' their peers in how to produce sellable images and access paying customers via anonymous payment systems without an adult 'facilitator'. ${ }^{8}$ Research suggests a range of motivations for children to engage in this behaviour, including to meet their families' financial needs; to

5 B Pulta, 'Online Child Exploitation Reports in PH Surge Amid Covid-19: DOJ', Philippine News Agency, 25 May 2020, retrieved 21 November 2020, https://www.pna. gov.ph/articles/1103852.

6 UNICEF, A Systematic Literature Review of the Drivers of Violence Affecting Children: the Philippines, 2016, p. 6, https://www.unicef.org/philippines/media/501/file/ National $\% 20$ Baseline $\% 20$ Study $\% 20$ on $\% 20$ Violence $\% 20$ Against $\% 20$ Children $\% 20$ in $\% 20$ the $\% 20$ Philippines: $\% 20$ Systematic $\% 20$ literature $\% 20$ review $\% 20$ of $\% 20$ drivers $\% 20$ of $\% 20$ violence $\% 20$ affecting $\% 20$ children $\% 20$.pdf; see also WeProtect Global Alliance, Global Threat Assessment 2018: Working together to end the sexual exploitation of children online, 2018, pp. 5-9 and 14, https://www.weprotect.org/wp-content/ uploads/Global-Threat-Assessment-2018-EN.pdf.

7 M Abad, 'PH Government, Private Sector Launch Joint Campaign Against Online Child Sexual Abuse', Rappler, 22 October 2019, https:/ /www.rappler.com/moveph/ saferkidsph-campaign-against-online-child-sexual-abuse; No Author, 'New Campaign SaferKidsPH to Raise Awareness on Online Sexual Exploitation of Children', UNICEF, 22 October 2019, https://www.unicef.org/philippines/press-releases/ new-campaign-saferkidsph-raise-awareness-online-sexual-exploitation-children.

8 Plan International, Children and the Sex Trade in the Digital Age: A study on the commercial sexual exploitation of children in Metro Manila, The Girls Advocacy Alliance, 2018, p. 29, https://plan-international.org/publications/children-and-sex-trade-digital-age; Internet Watch Foundation, Trends in Online Child Sexual Exploitation: Examining the distribution of captures of live-streamed cbild sexual abuse, IWF, Cambridge, 2018, p. 11, https://www.iwf.org.uk/sites/default/files/inline-files/Distribution $\% 20$ of $\% 20$ Captures $\% 20$ of $\% 20$ Live-streamed $\% 20$ Child $\% 20$ Sexual $\% 20$ Abuse $\% 20$ FINAL.pdf; National Center for Missing and Exploitation Children (NCMEC), The Online Enticement of Children: An in-depth analysis of CyberTipline reports, 2017, retrieved 24 November 2020, https://www.missingkids.org/content/dam/missingkids/pdfs/ncmec-analysis/ Online $\% 20$ Enticement $\% 20$ Pre-Travel.pdf; Terre Des Hommes Netherlands, p. 23. 
have their own money to purchase clothes, gadgets, or drugs and alcohol; or in the hope of forming relationships with foreign men online.

The sole study on the impact of OCSE in the Philippines suggests higher levels of post-traumatic stress, lower self-esteem, severe educational delays, and an increased risk of entering prostitution among victims.$^{10}$ However, the long-term effects of OCSE, whether facilitated by an adult or involving self-generated material, on the mental, physical, sexual, and social wellbeing of children is unknown and research is greatly needed to address this gap.

The primary interventions against OCSE in the Philippines are to identify and prosecute perpetrators and conduct OCSE awareness campaigns and education about online safety. These are important. However, professionals living in communities where OCSE is common observe that law enforcement activities are not a deterrent, ${ }^{11}$ and may actually be detrimental and traumatising for children. ${ }^{12}$ Similarly, research has shown that advanced law enforcement activities have little preventive effect on all forms of exploitation. ${ }^{13}$

\section{The Way Forward}

In my opinion as a health professional with ten years of experience working in the Philippines, OCSE should be regarded as a sexual and reproductive health (SRH) outcome. As with other SRH outcomes, it does not occur in a void but is influenced by a 'complex web of interrelated factors that operate at different levels. ${ }^{14}$ Social determinants such as poverty, family breakdown and dysfunction, poor parenting and supervision of children are pervasive in the

9 Terre Des Hommes Netherlands, pp. 17-23; UNICEF, p. 63; Plan International, p. 62.

10 Terre Des Hommes Netherlands, p. 48.

11 Renewsiya Foundation and Consuello Zobel Alger Foundation, A Healthy Me: Understanding and enhancing the impact of a bealth and wellbeing program for Filipina adolescents, April 2020, p. 46, http://www.renewsiya.org/wp-content/uploads/2020/11/ A-Healthy-Me-Research-Report-November-2020.pdf.

12 Plan International, p. 61.

13 L Kiss and C Zimmerman, 'Human Trafficking and Labor Exploitation: Toward identifying, implementing, and evaluating effective responses', PLoS Medicine, vol. 16, no. 1, 2019, https://doi.org/10.1371/journal.pmed.1002740.

14 V Chandra-Mouli, C Lane and S Wong, 'What Does Not Work in Adolescent Sexual and Reproductive Health: A review of evidence on interventions commonly accepted as best practices', Global Health: Science and Practice, issue 3, 2015, pp. 333-340, https:// doi.org/10.9745/GHSP-D-15-00126. 
Philippines. ${ }^{15}$ Furthermore, rapidly changing patterns of sexual activity, existing sociocultural norms, and a lack of evidence-based programmes, among other issues, result in other poor SRH outcomes such as teenage pregnancies, HIV/ AIDS and sexually transmitted infections, and sexualised violence against children. ${ }^{16}$

As is also true with interventions that are effective at reducing human trafficking, strategies to address OCSE and other SRH outcomes must be founded on a deep understanding of the underlying causal pathways and contextual factors for specific populations. ${ }^{17}$ Given the known determinants of OCSE, this must include long-term interventions at the household and community level which address poverty, enhance educational and employment opportunities, provide access to comprehensive SRH education for both girls and boys and their parents, and strengthen the family unit.

Whilst national legislation in theory supports this approach, multiple factors such as fragmentation of services, lack of sustained funding, and poor cooperation at the local government level limit programme reach and implementation. ${ }^{18}$ Progress is also disrupted by incongruous government policies and laws, including those that require a guardian's consent for children and youths under 18 years to access SRH services, but hold that children as young 12 can provide sexual consent and

15 UNICEF p. 6; J Melgar, et al., 'Assessment of Country Policies Affecting Reproductive Health for Adolescents in the Philippines', Reproductive Health, vol. 15, no. 205, 2018, https://doi.org/10.1186/s12978-018-0638-9; S Q Arguilla and J M Habitan, How Filipino Adolescents Communicate With Their Parents, and Vice Versa, Topics About Sexual Behavior and Reproductive Health, Undergraduate Thesis, College of Mass Communication, University of the Philippines Diliman, Quezon City, April 2014, retrieved 5 March 2021, http://iskwiki.upd.edu.ph/flipbook/viewer/?fb=2010-53196-HOWFILI\#page-1; M P N Marquez, M Kabamalan, and E P Laguna, Ten Years of Traditional Contraceptive Method Use in the Philippines: Continuity and change, DHS Working Papers No. 130, ICF, Rockville, July 2017.

16 Philippine Statistics Authority (PSA) and ICF International, Philippines National Demographic and Health Survey 2013, 2014, p. 61, https://dhsprogram.com/pubs/pdf/ fr294/fr294.pdf; Department of Health and Epidemiology Bureau of the Philippines, HIV/AIDS \& ART Registry of the Philippines, August 2019, 2020, https://www. aidsdatahub.org/sites/default/files/publication/EB_HARP_August_AIDSreg2019. pdf; E G Vista, 'Updates on Sexually Transmitted Infections in the Philippines', Journal of the Philippine Dermatological Society, vol. 27, no. 1, 2018, pp. 8-10; Council for the Welfare of Children (CWC) and UNICEF, National Baseline Study on Violence Against Children in the Philippines, 2016, p. 6, https://www.unicef.org/philippines/reports/ national-baseline-study-violence-against-children-philippines.

17 Kiss and Zimmerman; Chandra-Mouli, Lane and Wong.

18 Plan International, pp. 61-62. 
be held criminally liable at the age of $15 .^{19}$

A large body of evidence confirms that comprehensive SRH education can have a significant impact on SRH outcomes. ${ }^{20}$ Nascent research also suggests that this impact can be extended to related issues and, thus, experts recommend the inclusion of topics such as internet sexuality and gender-based violence. ${ }^{21}$ However, to be effective, SRH programmes must be holistic and intensive, using activity-based and learner-centred educational methodologies. They should be sustained across multiple developmental stages and implemented at the community level, with adequate attention given to the quality and fidelity of the programme. ${ }^{22}$ Whilst Philippine law and national government policies overtly provide a strong mandate for comprehensive SRH education, current SRH programmes are typically of limited scope and reach and use lecture-style, facilitator-directed educational methodologies. Thus, they are unlikely to be effective.

Children are considered social agents, although it is recognised that how this is conceptualised depends on an individual's or societies' moral and political constructions of childhood. ${ }^{23}$ However, it is clear that their agency comprises a mix of vulnerability and resilience, reflected in their complex and nuanced reasons for involvement in online sexual exploitation. ${ }^{24}$ Given these recognised vulnerabilities, the potential power imbalances encountered online, and the potential long-term impact of OCSE, they are entitled to special protection online. $^{25}$ This must involve directly reaching children with evidence-based

19 A J Rabe, Raising the Alarm: A policy brief on increasing the age of statutory rape, Consuelo Zobel Alger Foundation, August 2020, p. 7.

20 United Nations Educational, Scientific and Cultural Organization (UNESCO), International Technical Guidance on Sexuality Education: An evidence-informed approach, UNESCO, Paris, 2018, pp. 13-17, retrieved 13 March 2020, https://unesdoc.unesco. org/ark:/48223/pf0000260770/PDF/260770eng.pdf.multi.

21 Ibid., pp. 17-20; P Montgomery and W Knerr, Review of the Evidence on Sexuality Education: Report to inform the update of the UNESCO international technical guidance on sexuality education, UNESCO, Paris, 2018, p. 17, https://unesdoc.unesco.org/ark:/48223/pf0000264649.

22 UNESCO; Chandra-Mouli, Lane and Wong.

23 L Bordonaro, 'Agency Does Not Mean Freedom. Cape Verdean street children and the politics of children's agency', Children's Geographies, vol. 10, issue 4, pp. 413-426, https://doi.org/10.1080/14733285.2012.726068.

24 Ibid; N Mai, "Tampering with the Sex of "Angels": Migrant male minors and young adults selling sex in the EU', Journal of Ethnic and Migration Studies, vol. 38, issue 8, 2011, pp. 1237-1252, https://doi.org/10.1080/1369183X.2011.590927; Greijer and Doek, p. 25.

25 Greijer and Doek, p. 11. 
programmes and services which understand and acknowledge the different lenses which children have, including regarding their internet sexuality. ${ }^{26}$ Failure to do so denies their rights to comprehensive SRH education which imparts the skills they need to avoid or minimise risks and maximise their wellbeing in both the online and offline worlds. Children must have access to a range of economic and educational opportunities and social services in order to be protected and protect themselves from sexual and economic exploitation and anything that might 'interfere with their education, or be harmful to their health and physical, mental, spiritual, moral, or social development'. ${ }^{27}$ Given the rising numbers of reported OCSE cases, the time to start implementing these interventions is now.

Melinda Gill is the founding director of Renewsiya Foundation. She is a physician with a background in family medicine, women and children's health, and international health programming. She has lived in the Philippines for ten years where her work includes programmes to improve health outcomes among vulnerable populations, including survivors of trafficking and other forms of abuse and exploitation, and the recovery and reintegration of survivors through supported employment. Email: melinda.gill@renewsiya.org

26 Plan International, p. 10.

27 United Nations General Assembly, Convention on the Rights of the Child, 1989. 